\title{
Effects of Interest Rate and Debt on Equity Investment
}

\author{
Bodiseowei C. Obudah* and Steve S. Tombofa \\ Department of Economics, Niger Delta University, Wilberforce Island, Bayelsa State, Nigeria
}

\begin{abstract}
Equity investment is an important component of domestic investment and for over two decades Nigeria has witnessed volatility in the value of equity investment. The objectives of the study are to examine the effects of interest rate and domestic debt on private equity investment growth in Nigeria covering the 1987-2010 period as well as to determine if government borrowing crowds out private investment and borrowing. We used the co-integration technique to test the long run relationship among the variables and went to use standard ordinary least squares technique and error correction analysis. The results show that domestic debt and GDP growth rate had a positive effect on equity investment as expected. On the other hand, monetary policy rate had a negative effect on equity investment. The results of this article have crucial implications on the desire by individuals, firms and governments to participate in the equity investment market and policymakers' decisions. The Nigerian government should take cognisance of the 25 percent debt-to-GDP benchmark as adopted by the Federal Executive Council in 2010 and the revision to 30 percent in view of recent realities or the international norm of 60 percent target. Furthermore, funds from debt should be used productively and avoid misappropriation. The monetary policy rate should be allowed to exhibit the interplay of the market forces so as to encourage both internal and external capital investment in the Nigerian economy.
\end{abstract}

Keywords: Domestic debt, equity investment, monetary policy rate, economic growth

\section{Introduction}

Most times, scarcity of resources to achieve macroeconomic goals prompts governments to rely on borrowing. Specifically, governments' reasons for both domestic and external borrowing have been: budget deficit financing, implementation of monetary policy, development of the financial sector (deepening of the financial sector), large public expenditure growth, narrow revenue base and low output growth. Interest rate is basically the cost of such capital being borrowed. Traditionally, higher government borrowing from the domestic economy would increase the cost of borrowing. This is believed to have a negative impact on private investment.

Over the years, Nigeria met its debt commitment through regular servicing; this had been done at the expense of key social services such as health, education, water and sanitation. Nigeria has spent immensely in debt servicing. Recently, attention has shifted to domestic borrowing which increases multiplicatively every year. This may not be unconnected with the critical views expressed by both local and international financial organizations against the negative impact of external borrowing on growth and development indicators.

${ }^{*}$ Corresponding author.
Public debt is an important source of revenue to the government for building needed infrastructure which is requisite to stimulate economic progress. However, its effect on the level of private equity investment needs to be estimated. In this light, this paper seeks to (i) analyse recent trends in the composition of public debt in Nigeria and (ii) assess the impact of domestic debt and interest rate on private equity investment.

\section{Debt and Equity Investment in Nigeria}

\section{Debt in Nigeria}

In general, there are three ways the government can borrow: (i) by selling gilt-edged securities, (ii) by printing money, and (iii) by obtaining loans from internal and external sources.

The external debt era lasted for over three decades. External debt was assuaged in 2005 when the Paris club forgave most of Nigeria's external debt After 2005, governments reverted into internal borrowing. Data on domestic debt shows that in 2000, Nigeria owed about N898253.9 million. This figure rose to about N2320.31 billion in 2008. As at December, 2010, the internal debt profile was put at above N4 trillion. Table 1 shows that from 1991 to 2010 debt to GDP ratio surpassed the domestic debt benchmark of 30 percent. This trend is not too healthy for an ailing economy like Nigeria. 
Table 1. Domestic Debt in Nigeria, 1981 - 2010

\begin{tabular}{|c|c|c|c|}
\hline Year & $\begin{array}{c}\text { Domestic } \\
\text { Debt (N'M) }\end{array}$ & $\begin{array}{c}\text { Domestic } \\
\text { Debt }(\% \text { of } \\
\text { GDP }) \\
\end{array}$ & $\begin{array}{c}\text { Domestic } \\
\text { Debt Growth } \\
(\%) \\
\end{array}$ \\
\hline 1981 & 11192.60 & 4.00 & 27.84 \\
\hline 1982 & 15007.6 & 5.61 & 25.42 \\
\hline 1983 & 22221.4 & 8.09 & 32.46 \\
\hline 1984 & 25672.1 & 12.11 & 13.44 \\
\hline 1985 & 27949.1 & 12.77 & 8.15 \\
\hline 1986 & 28438.7 & 13.57 & 1.72 \\
\hline 1987 & 36789.1 & 13.89 & 22.70 \\
\hline 1988 & 47029.6 & 16.73 & 21.77 \\
\hline 1989 & 47049.6 & 19.87 & 0.04 \\
\hline 1990 & 84093.1 & 17.59 & 44.05 \\
\hline 1991 & 116198.7 & 31.69 & 27.63 \\
\hline 1992 & 177961.7 & 42.82 & 34.71 \\
\hline 1993 & 273836.4 & 64.75 & 35.01 \\
\hline 1994 & 407582.7 & 99.41 & 32.81 \\
\hline 1995 & 477733.9 & 144.84 & 14.68 \\
\hline 1996 & 419975.6 & 162.64 & -13.75 \\
\hline 1997 & 501751.1 & 139.05 & 16.30 \\
\hline 1998 & 560830.2 & 161.39 & 10.53 \\
\hline 1999 & 794806.6 & 179.65 & 29.44 \\
\hline 2000 & 898253.9 & 241.45 & 11.52 \\
\hline 2001 & 1016974 & 251.62 & 11.67 \\
\hline 2002 & 1166001 & 234.76 & 12.78 \\
\hline 2003 & 1257120 & 244.17 & 7.25 \\
\hline 2004 & 1297765 & 238.28 & 3.13 \\
\hline 2005 & 1275076 & 230.95 & -1.78 \\
\hline 2006 & 2082007 & 214.00 & 38.76 \\
\hline 2007 & 2941814 & 328.26 & 29.23 \\
\hline 2008 & 2320310 & 345.1802 & -26.79 \\
\hline 2009 & 3228030 & 450.245 & 28.12 \\
\hline 2010 & 45518240 & 5869.34 & 92.91 \\
\hline
\end{tabular}

Source: Debt Management Office (DMO)

The external and securitised domestic debt stock of the federal and state governments hit a total of N7.55 trillion at the end of 2012 representing an increase of marginal rise of about two per cent over the N7.45 trillion recorded at the end of 2011. Nigeria's domestic debt is currently 17.8 per cent of GDP which is far below the 30 per cent target set for the economy and much more below the international norm of 60 per cent target. Her debt service to revenue is 19 per cent as against the general norm of 30 per cent.

\section{Equity investment in Nigeria}

Invest $\mathrm{AD}$ in one of its studies surveyed 158 global institutional investors and established that $51 \%$ of respondents believed that Africa would be the most attractive region for investment growth, with all of the investors expressing their intent to have some exposure to Africa by 2016. Nigeria is said to be the second largest economy in Sub-Saharan Africa (SSA) with a private equity (PE) sector which accounts for about $10 \%$ of the region's private equity capital (Seyi and Ighodalo, 2009). In 2011, private investment in Sub-Saharan Africa was reported to be at $\$ 3$ billion. South Africa had the largest share of about $\$ 1.86$ billion while Nigeria followed closely with about $\$ 1$ billion. However, the Nigerian share of the total equity investment was as a result of the $\$ 750$ million invested in Union Bank Plc by a consortium led by Africa Capital Alliance (Patrick \& Afego, 2012).

Unlike other advanced economies where private equity deals mainly consist of leveraged buyouts, the predominant forms of private equity deals in Nigeria are management buyouts and restructuring. Notable management buyouts and restructuring include the Actis investment of US\$134m in Diamond Bank Nigeria Plc, and other investments in UAC of Nigeria Plc, Starcomms Nigeria Plc (Starcomms) and the Palms Shopping Mall, from which it has successfully divested. Also important are ECP's investment in Notore Chemical Industries Limited, Intercontinental Bank Plc and Starcomms; African Capital Alliance's successful investment in MTN Nigeria Communications Limited, the Associated Bus Company Plc, a transportation company, Cornerstone Insurance Plc and Linkserve Limited; and Ethos' US\$130m investment in Oceanic Bank International Plc (Seyi \& Ighodalo, 2009).

Over the years, private equity investment in Nigeria has been directed to banking, telecommunications, information and communications technology, oil and gas, real estate and construction, media and entertainment, food and agro-allied products. More often, these sectors enjoy tax incentives for investors, deliberate government policies to create an enabling environment for such businesses and sectoral reforms have also induced investors' interest in the aforementioned areas.

Basically, private equity investment comes in form of venture capital, management buy-outs and restructuring. Such investments could be made through initial public offer, offer for subscription, tender offer, rights offer, private placement, stock exchange introduction, etc. An offer for subscription is the issue of shares or debentures made directly by the company to the public. The proceeds of the issue go directly to the company to finance its fixed assets. A right offer is an offer to the existing shareholders of the company, usually at a price lower than the current market price (ICAN, 2010).

Table 2 shows a persistent increase in equity investment except in 1988 and 2010. The CBN deliberately influences the cost of borrowing for private sector investors by adjusting the minimum rediscount rate which was renamed the monetary policy rate in 2006 . Monetary policy rate which is a prominent instrument of monetary policy was volatile in the 1988-2010 period. It attained a high of $26 \%$ in 1993 . However, the monetary policy rate from the highest rate of 19 percent recorded in 2012 to a gross 6 percent in 2010. This trend is encouraging and believes to have contributed to increased investment level in the Nigerian economy. 
Table 2. Nigeria: Value of equities and monetary policy rate, 1987-2010.

\begin{tabular}{llc}
\hline Year & $\begin{array}{l}\text { Value of Equities } \\
\text { (N'M) }\end{array}$ & $\begin{array}{c}\text { Monetary Policy } \\
\text { Rate (MPR) }\end{array}$ \\
\hline 1987 & 30.6 & 12.75 \\
1988 & 24.8 & 12.75 \\
1989 & 27.9 & 18.50 \\
1990 & 66.9 & 18.50 \\
1991 & 143.4 & 14.50 \\
1992 & 400 & 17.50 \\
1993 & 456.2 & 26.00 \\
1994 & 793.6 & 13.50 \\
1995 & 1,788 & 13.50 \\
1996 & 6916.8 & 13.50 \\
1997 & 10222.6 & 13.30 \\
1998 & 13555.3 & 14.30 \\
1999 & 14071.2 & 18.00 \\
2000 & 28145 & 13.50 \\
2001 & 57648.2 & 14.30 \\
2002 & 59404.1 & 19.00 \\
2003 & 113882.5 & 15.75 \\
2004 & 223772.5 & 15.00 \\
2005 & 254683.1 & 13.00 \\
2006 & 36647637.30 & 12.25 \\
2007 & 137852243.50 & 8.75 \\
2008 & 192867507.70 & 9.75 \\
2009 & 101724204.40 & 6.00 \\
2010 & 93332072.10 & 6.00 \\
\hline
\end{tabular}

Sources: (i) CBN Annual Report and Statement of Accounts (various issues) (ii) CBN Annual Report (various issues)

\section{Literature Review}

Literature on the effect of debt especially domestic debt and interest rate on private equity investment is diverse and mixed. Empirical studies have found that high domestic debt leads to an increase in the level of financial deepening. Abbas and Christensen (2007) asserted that the government is a big player and that the presence of a large and liquid market for government bonds can promote the development of the corporate bond market by building the required minimum size, supplying a benchmark yield curve, and providing the necessary trading infrastructure. They opined that the availability of a well-working market for domestic debt can provide domestic savers with an alternative to investing abroad and thus reduce capital flight and can convince domestic agents to bring their savings back into the formal financial system generating large benefits in terms of financial depth and reduction of the black economy. As asserted, this would improve the level of financial deepening and growth in the economy. They further observed that the presence of limited demand for bonded instruments, market creation can become crowding out and excessive reliance on domestic government bonds can stunt the market for corporate bonds.

In the same vein, Kumhof and Tanner (2005) suggested that rather than being a symptom of financial repression, holdings of public debt are largely voluntary and improve the working of the financial sector in countries characterized by poor institutional quality and lack of collateral. In some countries a liquid market for government bonds can foster financial sector development, can lead to a more competitive setting for interest rates, and can improve the effectiveness of monetary policy.

Eichengreen and Leungnaruemitchai (2004) found no significant correlation between the size of the domestic government bond market and the size of the domestic private bond market and argued that the benefits in terms of market creation balance the costs in terms of crowding out. This suggests an equivalent negative and positive effect which results in a zero level effect.

There are also important interactions between domestically issued government debt and the functioning of the banking sector. Also here the effect can go either way. Most analysts found that in emerging market countries banks are the main holders of government bonds as a source of vulnerability and is a signal that government debt crowds out credit to the private sector.

A high level of equity investment in any economy portends a great level of potential growth and development. First, in classical theory investment is a function of interest rate while the Keynesians postulated that investment is a function of income and the rate of interest. Both the naive and flexible versions of the accelerator theory of investment see investment as a function of output growth. An increase in output is expected to bring about additions in the economy's capital stock (net investment). The flexible accelerator removes the assumption that capital stock is optimally adjusted without any time lag. According to the accelerator theory of investment, the relationship between investment and output is specified as:

$N I=k \Delta Y$

where NI is net investment, $\mathrm{k}$ is capital-output ratio and $\Delta Y$ is change in output. This implies that if the level of output remains constant, net investment will be zero. The desired stock of capital $\mathrm{K}^{*}$ is a function of expected output $Y^{e}$, user cost of capital $p$ and the real wage rate $w$ :

$K^{*}=f\left(Y^{e}, p, w\right)$

When real output changes, the desired stock of capital is a function of the user cost of capital and the marginal productivity of capital but if output is unchanged, the desired stock of capital is a function of the user cost of capital and the cost saving associated with employing fewer workers and more capital to produce a specific level of output. The user cost of capital is the real financial cost associated with acquiring real capital and the rate of depreciation.

The user cost of capital is lowered by increasing the real money supply and by fiscal policy regulations of the economy (investment tax 
credit, accelerated depreciation, etc). Domestic debt is a fiscal policy instrument. A change in the level of domestic debt is believed to affect the rate of interest and level of investment in the economy.

\section{Methodology, Data and Results}

Secondary data were the basis for this study. The relevant data were sourced from the Central Bank of Nigeria Statistical Bulletin, various publications of CBN Annual Report and Statement of Accounts and the Debt Management Office. The trends in domestic debt were explained and established using descriptive statistics. The lag period for this study is 24 years, i.e. 1987 to 2010 .

\section{Model specification}

Domestic debt is believed to have a crowding-out effect on equity investment level in an economy. One linear model is specified to analyse how domestic debt and interest rate affect equity investment.

$E I N V=\alpha+\delta D O D+\gamma \mathrm{MPR}+\phi G R W T+\varepsilon$

where; EINV is equity investment, MPR is monetary policy rate, DOD denotes domestic debt and GRWT is GDP growth rate. Real GDP growth was added as an explanatory variable to augment monetary policy rate and debt-GDP ratio.

Equation (3) was further transformed to reflect equity investment and domestic debt as ratios of real gross domestic product, $E I N V G D P=\alpha+\delta$ DODGDP $+\gamma \mathrm{MPR}+\not G R W T+\varepsilon$
The a priori expectations: $\delta<0, \gamma<0, \phi>0$

The ordinary least squares econometric technique was used because it is very reliable and widely used by researchers to measure the impact of variables. Generally, the properties of the time series variables were tested. A unit root test was also carried out on each of the variables to test the stationarity of each variable. Specifically, the augmented Dickey Fuller technique was used for the unit root test. The ADF was chosen rather than the DF approach because it incorporates serial correlation, that is, the error term is unlikely to be white noise. Hence, the ADF adds the lagged values of the dependent variable in order to eliminate autocorrelation. This was to ensure nonspurious econometric results. Co-integration test was carried out to test for the long-run relationship among the variables. It is also important we use the Engle-Granger test for co-integration since it uses a parametric augmented Dickey-Fuller (ADF) approach.

\section{Data analysis and results}

Figure 1 shows the level of domestic debt in the period 1970 to 2010. The domestic debt trend increased sharply in 2010. This might be as a result of the government avoiding the external debt trap again. This trend of skyrocketing debt is not the best for the economy. This is because the servicing of debt will be done at the expense of building social infrastructure and capacity.

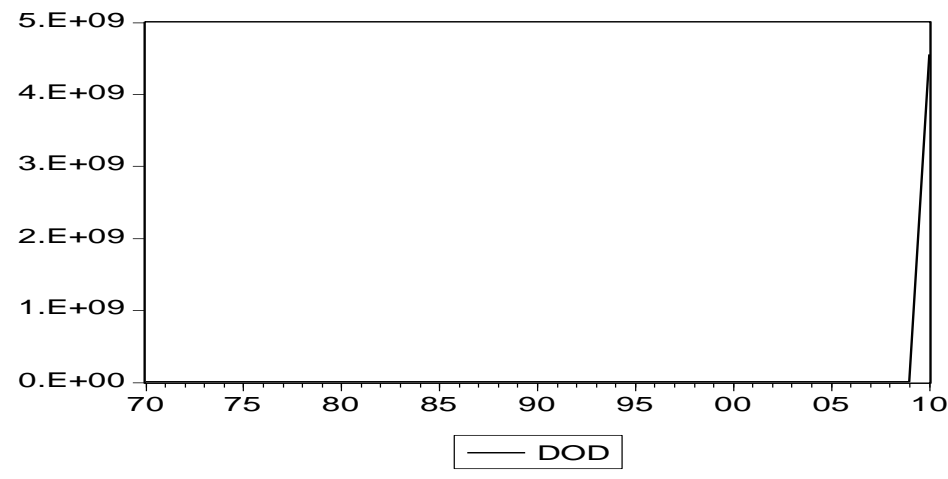

Figure 1. Nigeria: Domestic debt trend, 1987-2010.

Figure 2 shows a constantly declining monetary policy rate since 2002 . This would encourage investment in the economy. 


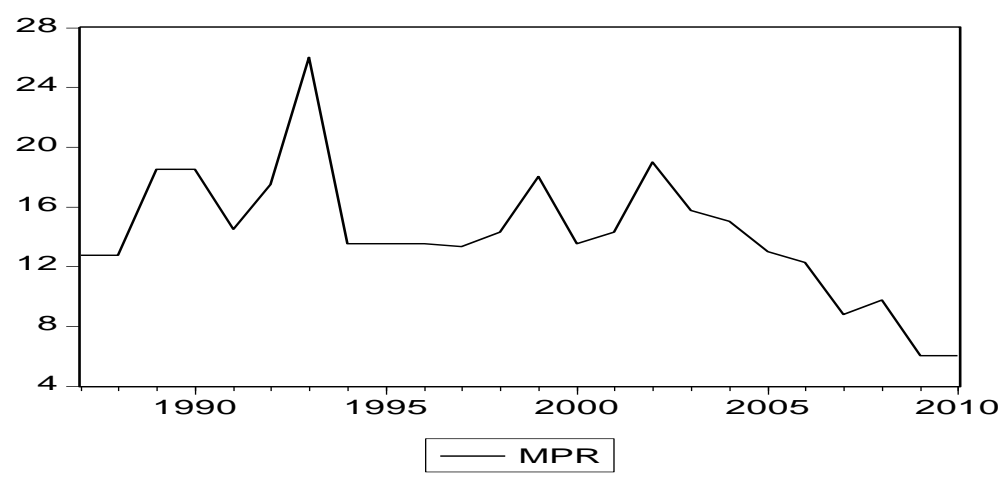

Figure 2. Nigeria: Monetary policy rate trend, 1987-2010.

Figure 3 shows that there was a minimal level of growth in equity investment between 1987 and 2005. The Central Bank of Nigeria statistical data reported a sharp increase in equity investment between 2005 and 2010 as depicted in figure 3.

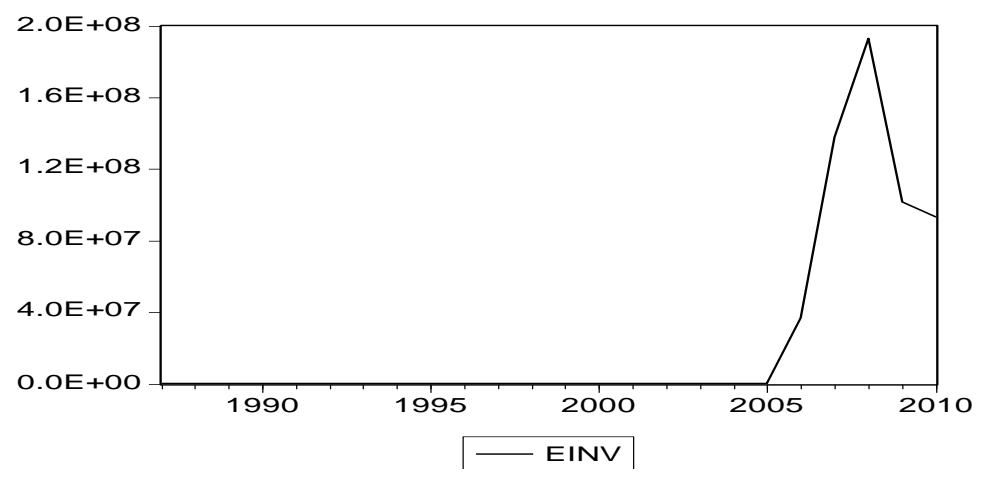

Figure 3. Nigeria: Equity investment trend, $1987-2010$.

The ADF test statistic for DODGDP, EINVGDP, MPR and GRWT show that all variables integrated at order 1 (see Table 3). This suggests that first differencing is sufficient or these variables do not have two unit roots. It technically implies that data are only relevant for short run economic analysis and prediction.

Table 3. Unit root test result using ADF procedure.

\begin{tabular}{ccccc}
\hline Variable & ADF Test Statistic & $\begin{array}{c}\text { Critical } \\
\text { Value (5\%) }\end{array}$ & $\begin{array}{c}\text { Order of } \\
\text { integration }\end{array}$ & Lag Length \\
\hline DODGDP & -2.011127 & -1.9583 & $\mathrm{I}(1)$ & 1 \\
EINVGDP & -4.957978 & -1.9583 & $\mathrm{I}(1)$ & 1 \\
MPR & -5.631363 & -1.9583 & $\mathrm{I}(1)$ & 1 \\
GRWT & -3.323234 & -1.9583 & $\mathrm{I}(1)$ & 1 \\
\hline
\end{tabular}

In order to ascertain the convergence of these variables at the long run, co-integration test was carried out. The co-integration test shows that there are 2 co-integrating equations at the $5 \%$ level of significance and one co-integrating equations at the $1 \%$ level of co-integration as shown in Table 4.

Table 4. Johansen's co-integration test results.

\begin{tabular}{|c|c|c|c|c|}
\hline $\begin{array}{l}\text { Hypothesized } \\
\text { No. of CE(s) }\end{array}$ & Eigenvalue & $\begin{array}{l}\text { Trace } \\
\text { Statistic }\end{array}$ & $\begin{array}{l}5 \text { Percent } \\
\text { Critical Value }\end{array}$ & $\begin{array}{l}\text { 1 Percent } \\
\text { Critical Value }\end{array}$ \\
\hline None $* *$ & 0.890113 & 92.88984 & 62.99 & 70.05 \\
\hline At most $1 *$ & 0.612788 & 44.30712 & 42.44 & 48.45 \\
\hline At most 2 & 0.488351 & 23.43392 & 25.32 & 30.45 \\
\hline At most 3 & 0.326361 & 8.691337 & 12.25 & 16.26 \\
\hline
\end{tabular}

$*(* *)$ denotes rejection of the hypothesis at the $5 \%(1 \%)$ level

Trace test indicates 2 cointegrating equation(s) at the $5 \%$ level

Trace test indicates 1 cointegrating equation(s) at the $1 \%$ level 
Error-Correction Mechanism (ECM) is used to check the short run dynamics among explained (EINVGDP) and explanatory variables (DODGDP, MPR \& GRWT). It has been proved that long run relationship exists among the variables but there may be short term disequilibrium. Hence error correction mechanism is used to remove this divergence from long run equilibrium.

The error correction mechanism results in table 5 identify that DODGDP and GRWT have a positive effect on EINVGDP. A one percent increase in economic growth on the average increases equity investment by 41 percent. Both GRWT and MPR have the expected impact. A higher level of monetary policy rate (MPR) will lead to lower level of equity investment. DODGDP does not have the expected effect on equity investment. This suggests that domestic debt does not crowd-out equity investment in the Nigerian economy. In essence, the high level of domestic debt would have contributed to financial deepening. At the $5 \%$ level of significance, the overall model is significant. The adjusted $\mathrm{R}^{2}$ is encouraging with a 59 percent explanatory power. However, the speed of adjustment to equilibrium in EINV is low at 25 percent. Serial correlation problem among the variables is minimal at (1.45) Durbin-Watson statistic. The overall model is significant with an Fprobability of $(0.000745)$.

Table 5. Error correction mechanism results

\begin{tabular}{lc}
\hline Dependent Variable & EINVGDP \\
\hline Constant & 2308.678 \\
& $(0.348033)$ \\
$\Delta$ DODGDP & 6.636285 \\
& $(0.666280)$ \\
$\Delta$ GRWT & 41.76634 \\
& $(0.086454)$ \\
$\Delta \mathrm{MPR}$ & -197.3821 \\
& $(-0.576394)$ \\
ECM(-1) & -0.253304 \\
& $(0.00231)$ \\
Adj. R & 0.593282 \\
DW & 1.450190 \\
F-Stat & 7.418302 \\
& $(0.000745)$ \\
\hline
\end{tabular}

\section{Conclusion and Recommendations}

In this study we examined the effects of domestic debt and interest rate on equity investment in Nigeria between 1987 and 2010. The parsimonious ECM results suggest that domestic debt and GDP growth rate had positive effects on equity investment while monetary policy rate had negative effect on equity investment in Nigeria.

This paper recommends that Nigerian governments should take cognisance of the 25 percent debt-to-GDP benchmark as adopted by the Federal Executive Council (FEC) in 2010 and its revision to 30 percent in view of recent realities or the international norm of 60 percent target. The results of this article have crucial implications on the desire by individuals, firms and governments to participate in the equity investment market and policy-makers' decisions. It is important for the levels of government to drastically improve their internally generated revenue base. Furthermore, funds from debt should be used productively. The fungibility of debt funds to unproductive ventures makes it difficult for governments to service debt which has the danger of perpetually keeping the economy in the debt trap. The monetary policy rate should be allowed to exhibit the interplay of the market forces so as to encourage both internal and external capital investment in the Nigerian economy. Higher economic growth has a positive feedback effect on all sectors of the economy, hence Nigeria should strive as a nation to achieve higher level of economic growth.

Appendix table. Nigeria: Real economic growth, 1987-2010.

\begin{tabular}{cccc}
\hline Year & GDP Growth & Year & GDP Growth \\
\hline 1987 & -0.6 & 1999 & 2.8 \\
1988 & 10 & 2000 & 3.9 \\
1989 & 7.3 & 2001 & 4.6 \\
1990 & 8.2 & 2002 & 4.6 \\
1991 & 4.8 & 2003 & 9.6 \\
1992 & 3 & 2004 & 6.6 \\
1993 & 2.7 & 2005 & 6.5 \\
1994 & 1 & 2006 & 5.6 \\
1995 & 2.2 & 2007 & 6.5 \\
1996 & 3.4 & 2008 & 6.1 \\
1997 & 3.2 & 2009 & 7 \\
1998 & 2.4 & 2010 & 8 \\
\hline
\end{tabular}

Sources: (1)CBN Statistical Bulletin, various issues (2)CBN

Annual Report, various issues

\section{References}

Abbas S. M. \& J. E. Christensen (2007). The role of domestic debt markets in economic growth: An empirical investigation for low-income countries and emerging markets, IMF Working Papers, WP/07/127.

Central Bank of Nigeria (Various Issues), Statistical Bulletin.

Central Bank of Nigeria (CBN) (Various Issues), Annual Report and Statement of Accounts.

Eichengreen B. \& P. Luengnaruemitchi (2004). Why doesn't Asia have bigger bond market? NBER Working Paper Series, Cambridge.

Hansen, H., \& F. Tarp (2000). Aid effectiveness disputed, in foreign aid and development lessons learnt and directions for the future, F. Tarp, \& P. Hjertholm (eds) London: Routledge.

ICAN (2010). Strategic financial management, study pack, professional examinations II, VI Publishers, Lagos, Nigeria

Kumhof M. \& E. Tanner (2005). Government Debt: An Essential Role in Financial Intermediation, IMF Working Paper, 05/57, Washington: International Monetary Fund.

Nigeria, Debt Management Office (n.d). Retrieved from: www.dmo.gov.ng.

Patrick A. \& P. Afego (2012). Inflation boosts fixed income markets threatens equities, Business Day Web Team, Retrieved from: www.businessdayonline.com.

Seyi O. B. and Ighodalo (2009). Private Equity Transactions in Nigeria: Some Legal Considerations, Euromoney Handbook, Retrieved from: www.banwo-ighodalo.com 